\title{
METABOLIC STUDIES ON PROTEIN-DEPLETED PATIENTS RECEIVING A LARGE PART OF THEIR NITROGEN INTAKE FROM HUMAN SERUM ALBUMIN ADMINISTERED INTRAVENOUSLY ${ }^{1,2}$
}

\author{
By CHRISTINE WATERHOUSE,3 SAMUEL H. BASSETT,4 and JACOB W. \\ HOLLER, 5 WITH THE TECH NICAL ASSISTANCE OF KATHRYN Y. CUSSON \\ (From the Department of Medicine, University of Rochester, School of Medicine and Dentistry, \\ and the Medical Clinic of the Strong Memorial and Rochester \\ Municipal Hospitals, Rochester, N. Y.)
}

(Received for publication September 22, 1948)

\section{INTRODUCTION}

Protein depletion has long been recognized as detrimental to many bodily functions. The problem is particularly urgent in the chronically ill patient who is unable to ingest an adequate caloric or protein intake. During the past decade the search for parenteral substitutes for oral protein has proceeded apace, although frequently without due regard for the fact that retention of nitrogen can be expected only when a certain critical caloric intake supplement has been made available in the form of carbohydrate and fat (1-3).

Mixtures of the essential amino acids, protein hydrolysates, and human plasma have been used with some success (4-6). All, however, possess certain disadvantages. Protein hydrolysates and synthetic amino acid preparations may give rise to vomiting and other reactions; also the rapidity with which they are deaminated and excreted in the urine suggests that they are poor sources of

\footnotetext{
1 Part of this work was carried out under a contract between the University of Rochester School of Medicine and Dentistry and the Atomic Energy Commission. Partial support was received from the Committee on Growth, National Research Council, acting for the American Cancer Society, and from the Hochstetter Fund of the University of Rochester School of Medicine and Dentistry.

2 The albumin used in these studies was prepared by the American National Red Cross from the blood of voluntary donors. This material has been supplied to investigators by the American Red Cross as part of its National Blood Program. The opinions and conclusions are those of the authors and do not necessarily reflect the policy of the National Blood Program.

3 Henry C. Buswell Fellow in Internal Medicine.

4 Now at Veterans Administration Center, Los Angeles, California.

5 Bertha H. Buswell Fellow in Internal Medicine, now at Bradford Clinic, Bradford, Pennsylvania.
}

nitrogen $(4,6)$. Plasma, especially when derived from large pools, may carry serum jaundice; and its relatively high content of sodium is also a source of difficulty in patients who tend to collect edema. Moreover, the utilization of intravenously administered plasma protein has been the subject of some controversy during the past few years. It is generally conceded that positive nitrogen balances can be established in both animals and man by the intravenous administration of homologous plasma, provided that the dose is in excess of the minimum protein requirements. It is felt by some investigators $(7,8)$ that the positive balance obtained is an illusory affair and that the actual utilization is poor in some instances. On the other hand, Whipple and coworkers (9) believe that parenteral plasma protein can supply all the requirements for maintenance over a considerable period of time. This implies that there is an exchange between the tissues and the injected protein and that this exchange satisfies the need of endogenous metabolism.

When purified human serum albumin became available in large quantities through the Red Cross program, it was recognized to have certain advantages over other materials in common use. Briefly these are: its low content of sodium, the general freedom from reactions when given intravenously in moderate amounts, and the fact that it can be prepared free from the hazard of viral jaundice. It carries the stigma, however, of being deficient in both tryptophane and isoleucine $(10$, 11). This deficiency has been partially rectified by the inclusion of acetyltryptophane as a stabilizer. Yet in view of the reported deficiencies, studies on the nutritive value of albumin for man should be pertinent. Eckhardt and others (12) were unable to maintain nitrogen balance when 
$37.5 \mathrm{Gms}$. of albumin a day, administered orally together with an adequate caloric intake, were the sole source of protein. Supplements of dl tryptophane and $\mathrm{dl}$ isoleucine did not improve utilization. However, when $50 \mathrm{Gms}$. of albumin were given, nitrogen was retained. Two patients were maintained in positive balance on $37.5 \mathrm{Gms}$. of albumin daily when the albumin was given intravenously. They concluded that albumin could maintain nitrogen equilibrium in man when given either orally or intravenously in sufficient amounts and that supplements of tryptophane or isoleucine were unnecessary. It should be recalled, however, that maintenance of equilibrium, or positive nitrogen balance, in short periods of this sort is quite a different problem from satisfying growth or maintenance requirements over a long period of time.

Albright et al. (13) have offered indirect evidence for the utility of injected albumin or plasma protein in protein nutrition. In a study of hypoproteinemic patients they found retention of a sufficient quantity of phosphorus to indicate a conversion of as much as 50 per cent of the injected protein into cellular protein.

In view of the evidence at hand, it seemed pertinent to set up a series of experiments which would put the current theories to further test, particularly with respect to the fate of the albumin in the depleted patient. Subjects were chosen who were in need of protein and who were not acutely ill, since it was thought that the utilization of albumin might be more efficient in such individuals. The amount of albumin administered was placed at a level well above the probable basic protein requirements. In order to assure the best possible opportunity for conversion, the caloric intake was kept at as high a level as the patient would tolerate. None of the diets were protein-free, but, except in one instance, the amount of diet protein was too low to maintain nitrogen balance.

\section{PATIENT MATERIAL AND PROCEDURE}

G. V. was a 21-year-old white male who had developed rheumatic heart disease with mitral stenosis and insufficiency at the age of five years. Cardiac decompensation had occurred on two occasions, during both of which there had been transient jaundice, perhaps secondary to chronic passive congestion of the liver. At the time of the present studies, the rheumatic disease did not appear to be active, and the patient was compensated. He was, however, malnourished and appeared chronically ill. The basic diet provided 3300 calories and 2.6 Gms. of nitrogen. This was supplemented by the addition of $60 \mathrm{Gms}$. of beefsteak protein in two preliminary periods and subsequently by $60 \mathrm{Gms}$. of human albumin intravenously each day for a ten-day period.

E. G. was a 43-year-old white female who had been ill for ten months before the metabolic studies were begun. Her illness was characterized by migratory polyarthritis, irregular bouts of low-grade fever, transient accumulations of fluid in the pleural cavities, anorexia, and loss of weight. The diagnosis was never fully established in this patient, although it was believed that she had a generalized vascular disease, suggestive of periarteritis nodosa. At the time the metabolic observations were started, she was emaciated but afebrile, and appeared to be in a quiescent phase of her disease. She did not tolerate the type of low protein diet used in the other patients and a liquid formula providing 1200 calories and $8.2 \mathrm{Gms}$. of nitrogen was substituted in its place. Following a five-day control period, the intake was supplemented for 12 days by $60 \mathrm{Gms}$. daily of intravenous albumin.

W. R. was a 28-year-old female with a history of acute and chronic alcoholism. She was asymptomatic at the time of study and had no clinical evidence of liver disease. An inadequate diet associated with alcoholism had brought her weight below optimum. The basic diet in her case provided $4.2 \mathrm{Gms}$. of nitrogen and 2600 calories. Albumin was administered intravenously as in the other patients in the amount of $60 \mathrm{Gms}$. daily for 15 days.

Eugene G., a 26-year-old white male, presented the syndrome of neurocirculatory asthenia, but had no signs

TABLE I

Sex, height, weight, age and composition of basic diet of subjects receiving intravenous albumin

(All dietary values on per diem basis)

\begin{tabular}{|c|c|c|c|c|}
\hline Patient & G. V. & E. G. & W. R. & $\begin{array}{c}\text { Eugene } \\
\text { G. }\end{array}$ \\
\hline $\begin{array}{l}\text { Sex } \\
\text { Ht. (cm.) } \\
\text { Wt. (kg.) } \\
\text { Age (yr.) }\end{array}$ & $\begin{array}{c}\text { Male } \\
182.2 \\
56.1 \\
21\end{array}$ & $\begin{array}{c}\text { Female } \\
156.0 \\
38.7 \\
43\end{array}$ & $\begin{array}{c}\text { Female } \\
169.0 \\
57.2 \\
28\end{array}$ & $\begin{array}{c}\text { Male } \\
172.0 \\
56.6 \\
26\end{array}$ \\
\hline $\begin{array}{ll}\text { Daily calories } & \\
\text { Carbohydrates (Gms.) } & \text { (Gms.) } \\
\text { Fat } & \text { (Gms.) } \\
\text { Protein } & \text { (Gms.) }\end{array}$ & $\begin{array}{c}3355 \\
727 \\
46 \\
11.8\end{array}$ & $\begin{array}{r}1225 \\
109 \\
59 \\
55.5\end{array}$ & $\begin{array}{r}2643 \\
487 \\
68 \\
23.5\end{array}$ & $\begin{array}{c}2282 \\
450 \\
47 \\
17.6\end{array}$ \\
\hline \multicolumn{5}{|l|}{ Found by analysis } \\
\hline $\begin{array}{l}\mathrm{N} \text { Gms. } \\
\mathrm{Ca} \text { Gms. } \\
\mathrm{P} \text { Gms. } \\
\mathrm{K} \text { Gms. } \\
\mathrm{Na} \text { Gms. } \\
\mathrm{Cl} \text { Gms. }\end{array}$ & $\begin{array}{r}* 2.630 \\
.360 \\
.914 \\
- \\
-\end{array}$ & $\begin{array}{l}8.160 \\
1.540 \\
1.470 \\
- \\
-\end{array}$ & $\begin{array}{r}* 4.200 \\
.421 \\
1.140 \\
3.200 \\
=\end{array}$ & $\begin{array}{r}2.600 \\
.278 \\
.406 \\
3.860 \\
0.118 \\
0.159\end{array}$ \\
\hline
\end{tabular}

* Represent average values based on 5 days of continu. ous sampling. 
of organic disease. There was a history of suboptimal caloric intake for more than a year but no recent loss of weight. He was physically the most normal subject of the group and probably had no significant protein depletion at the time of the experiment. His basal diet provided 2300 calories and $2.6 \mathrm{Gms}$. of nitrogen per diem.

A summary of the basic data on these patients plus the analytical values found on their control diets is presented in Table I. The albumin used was also analyzed and found to contain in each $100 \mathrm{cc}$. (a 25 per cent solution) $3.90 \mathrm{Gms}$. of nitrogen, $14 \mathrm{mg}$. of phosphorus, 13.84 m.eq. of sodium, and .78 m.eq. of chloride.

\section{METHODS}

All subjects were admitted to the special Metabolic Ward for study where well-controlled balances could be conducted. Diets were weighed and cooked under the supervision of the dietician, and any food refused by the patients was saved for analysis. The major emphasis was placed upon the determination of the balance of nitrogen, calcium and phosphorus. In addition the potassium balance was determined for W. R. and the sodium, potassium and chloride balances were determined for Eugene G. Urine was collected in periods of 24 hours. Stools were saved in five-day pools and separated by carmine markers. The intake for elements entering into the calculation of the balance was determined either by analysis of sample diets duplicating in all respects the food as served to the patients, or by the method of continuous sampling as described by Bassett and Van Alstine (14). The analytical procedures were carried out as follows: nitrogen in the urine, diet and stool by macroKjeldahl; calcium of the diet, urine and stool by the gravimetric procedure (15); daily analyses of the urinary phosphorus were made by the method of Fiske and Subbarow (16); phosphorus in the diet and feces by the gravimetric method (15); sodium and potassium were determined by the internal standard method of flame photometry (17); chloride by the open Carius method (18). Serum proteins were determined colorimetrically (19) and fractionated by Howe's method; they were also measured by a method based on the electrophoretic pattern (20). Urinary protein was determined by a modification of the biuret method (19). The dye T 1824 was used to estimate plasma volume using Gibson's technique (21). Hematocrits and erythrocyte sedimentation rates were done as described by Wintrobe (22).

\section{RESULTS}

\section{Nitrogen balance}

The three subjects (G. V., W. R., and Eugene G.) who received a basic diet containing $4.0 \mathrm{Gms}$. or less of nitrogen a day were in negative nitrogen balance during the control periods, although from inspection of Figures 1, 3, 4 it is clear that they tended to approach equilibrium in the final preliminary days. E. G. (see Figure 2) who re- ceived slightly more than $8 \mathrm{Gms}$. of food nitrogen of good quality each day, retained nitrogen for the first five days, in spite of the low caloric intake. In her case, the need for protein was obviously great and the reduction in calories apparently had not reached the critical level (1) where retention of nitrogen is impossible. All four patients were found to be in markedly positive nitrogen balance during the first few days of albumin injections and in none was there an appreciable increase in the urinary nitrogen during this time. This is in marked contrast to the prompt increase in urinary nitrogen in $G$. V. (Figure 1) when he was fed beefsteak protein in an amount equivalent to the albumin injected. After the first few days on albumin, the nitrogen

\section{NITROGEN BALANCE AND URINE PROTEIN DURING INTRAVENOUS ALBUMIN}

G.V. AGE 21 MALE UNT NO. 182390
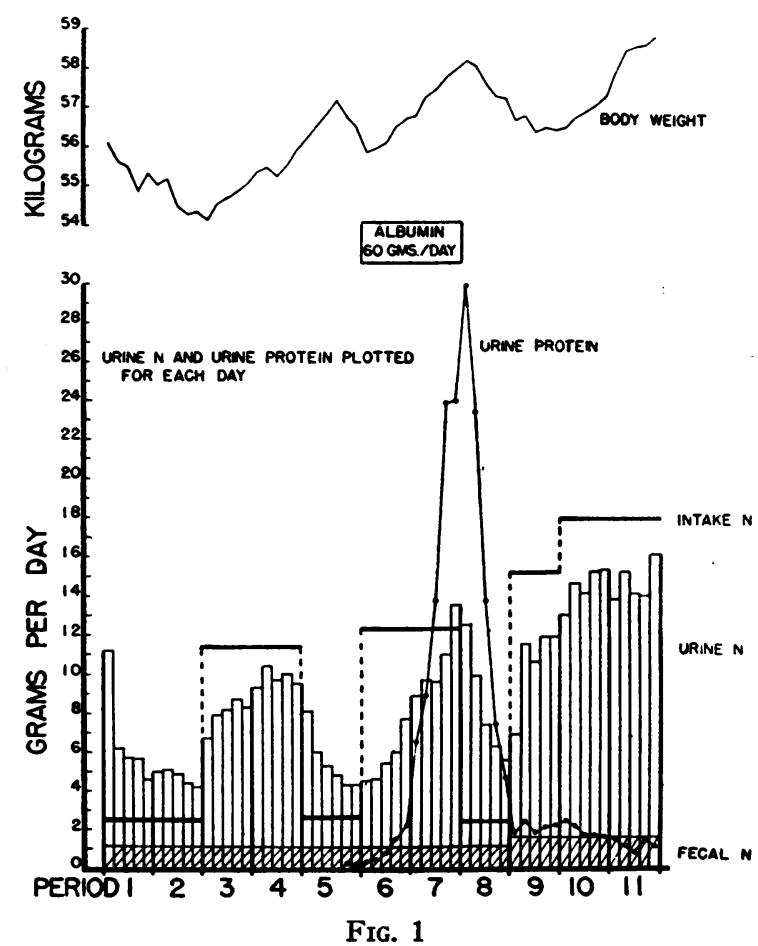

Positive nitrogen balances are indicated by the clear areas between the intake line and the columns representing the sum of urine and fecal excretion. An extension of these columns above the intake line denotes a negative balance.

The urine protein is given as grams of protein per 24 hours. 
NITROgen ballance and URINE PROTEN DURING INTRAVENOUS ALBUMMN

E.G. AGE 43 FEMALE UNIT NO 267749

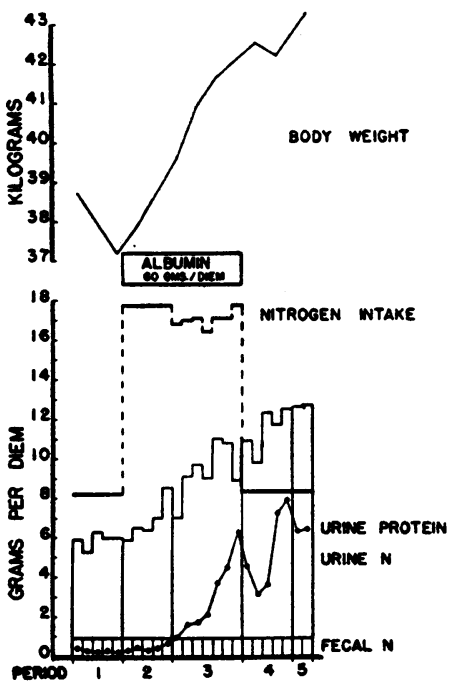

Fig. 2

For legend, see Figure 1.

of the urine began to increase and rose slowly but progressively until the experimental period was terminated. In only one instance, however (the case of G. V.), did the urinary nitrogen become so great as to produce a negative nitrogen balance. The reason for this negative balance is undoubtedly to be found in the marked proteinuria which this man developed. When the injections of albumin were discontinued, the urinary nitrogen did not immediately decline to the level of pre-albumin days, but remained well above that level so that the negative balance of the five postcontrol days was in excess of that encountered in a preliminary period of equal length. This can hardly be interpreted other than as catabolism of some of the albumin still remaining in the body.

\section{Proteinuria}

All the patients excreted protein in the urine at some time during the course of administration of albumin, but in only one subject, G. V., was a massive proteinuria encountered (see Figures 1-4). In his case distinct traces of albumin, although in amounts too minute for precise measurement, had appeared in the urine from time to time prior to parenteral albumin administration.
On the fourth day of the injections, however, there was a sharp rise in urinary protein which by the tenth day reached a maximum of $30 \mathrm{Gms}$. in 24 hours. This wastage of protein was undoubtedly responsible for the negative nitrogen balance at the end of the experimental period. The electrophoretic pattern of the urinary protein showed chiefly albumin with a trace of alpha globulin. The phenomenon of proteinuria was less marked in the remaining three patients, and its onset tended to be more delayed. At maximum E. G. excreted about 7 Gms. daily, Eugene G. $5 \mathrm{Gms}$. daily, while the amount excreted by W. R. did not rise above $3 \mathrm{Gms}$. in 24 hours. On cessation of injections of albumin, the proteinuria in these patients declined sharply or ceased altogether within five or six days.

\section{Body weight}

The two male patients (G. V. and Eugene G.) each gained about $2 \mathrm{~kg}$. in weight during the time albumin was given, while the two women showed

\section{NITROgen balance and lane proten dURING. INTRAMENOUS ALBUMIN}

WR. AGE 28 FEMALE UNIT NQ. 238476

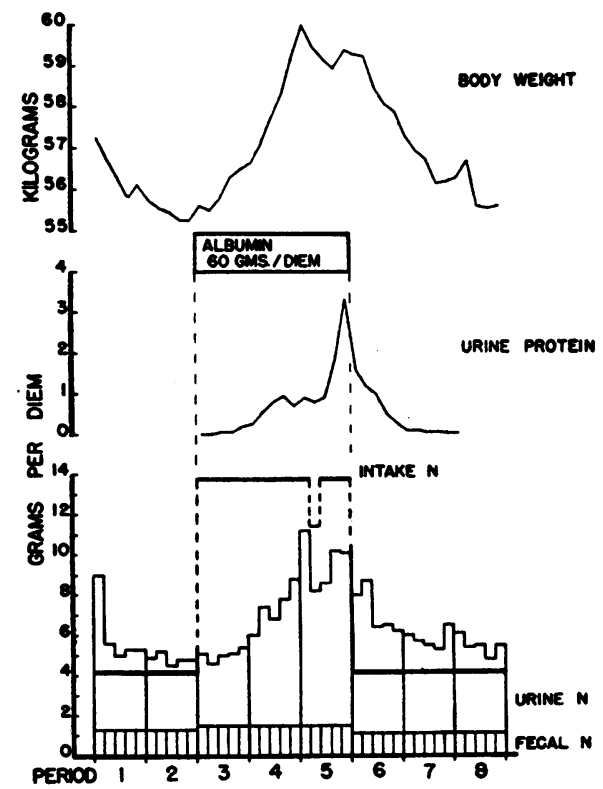

FIG. 3

For legend, see Figure 1. 


\section{NITROGEN BALANCE AND URINE PROTEIN DURING INTRAVENOUS ALBUMIN}

Eug.G. AGE 26 MALE UNT NO. 188107

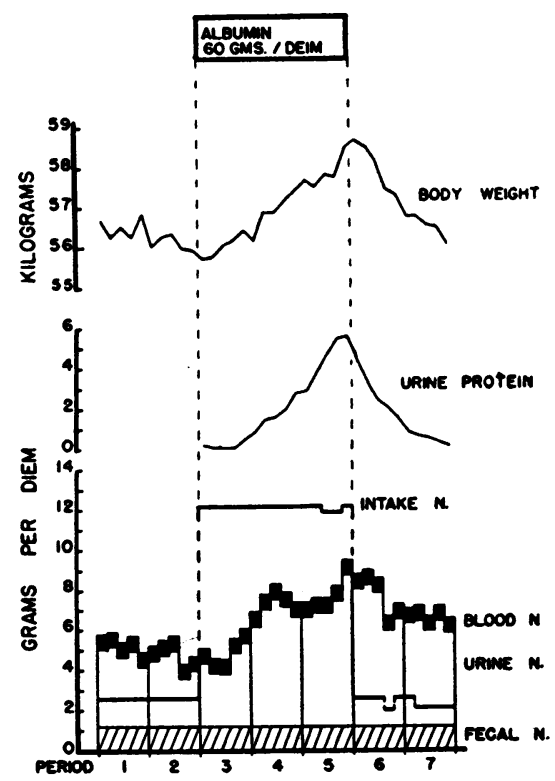

FIG. 4

For legend, see Figure 1. Blocks labeled "blood N" represent nitrogen removed in blood taken for analysis.

gains of about $5 \mathrm{~kg}$. (Figures 1-4). That the major factor in the weight gains of all patients was an expansion of the extracellular fluid volume, is suggested by the fact that the portion of albumin nitrogen apparently retained as protoplasm was quite inadequate to account for the weight gain in any patient. The mechanism of the large gain in extracellular fluid seen in the female patients was probably different in each case. Evidence to be brought out later suggests that albumin leaked into the extracellular fluid of E. G. where it tended to bind water. W. R., on the other hand, showed little evidence for the retention of large amounts of albumin in the extracellular fluid. She did, however, take large amounts of salt and water during this time and sodium retention was felt to be partially responsible for the accumulation of fluid. It will be noted (Figure 3 ) that some decrease in weight occurred before the injections of albumin were stopped, and that this coincided with a moderate restriction of the intake of salt and water.
Plasma protein and plasma volume

The rise in the concentration of plasma albumin above the control level was of the order of 2 Gms. per cent (Figures 5-8). The maximum concentration of albumin, $6.3 \mathrm{Gms}$. per cent, occurred in Eugene G. The concentration of globulin decreased as the albumin rose, but this was apparently an effect of dilution, since calculations of the total circulating globulin based on the increase in plasma volume showed no change. An expansion of the plasma volume to about 25 per cent above the initial values occurred in all cases but there was no change in the cell volume (except in the case of Eugene G. where rather large quantities of blood were removed for analysis). As a consequence the hematocrit fell. There was also a decrease in the erythrocyte sedimentation rate, presumably related to the higher concentration of plasma albumin.

\section{EFFECT OF NTRAVENOUS ALEUNN ON SERUM PROTENS, BLOOD VOLUME, HEMATOCRT AND ERYTHROCYTE SEDIMENTATION}

GV AGE 21 MALE UNT NO. 182390

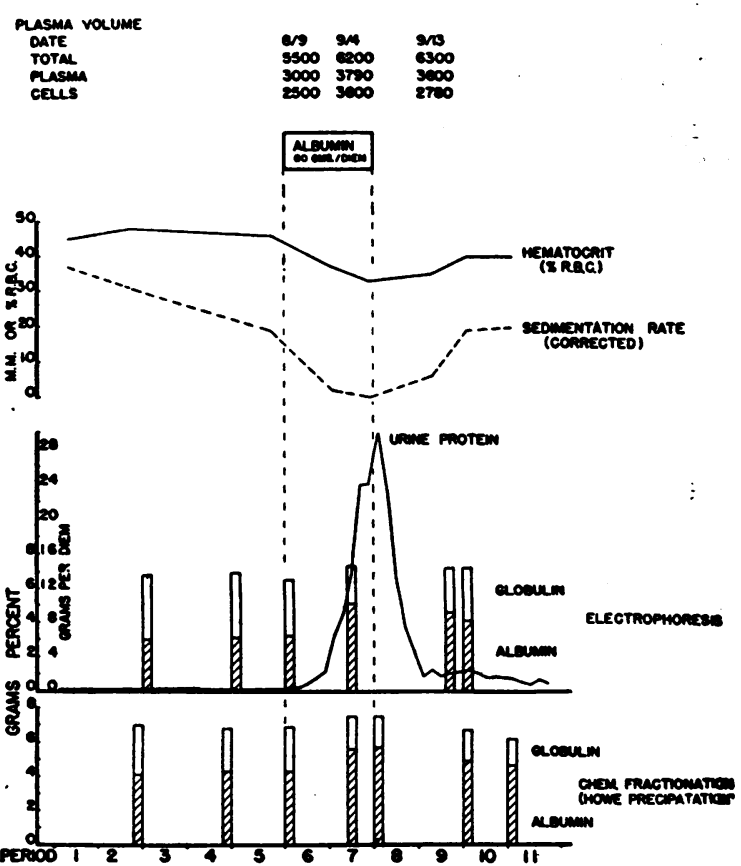

FIG. 5 


\section{Clinical course}

In the categories already discussed, i.e., nitrogen balance, proteinuria plasma proteins, plasma volume, hematocrit, and sedimentation rate, one notes a striking similarity in the reactions of the four patients. The sharply differing clinical responses, however, demonstrate the effect of the condition of the subject on the fate of the injected albumin.

Patient G. V. tolerated the injections of albumin well until the seventh day when he began to complain of loss of appetite and nausea. On the tenth day of albumin he was observed to be jaundiced. At no time was there any clear evidence of heart failure although he was known to have rheumatic heart disease and had had cardiac decompensation on two previous occasions. The jaundice and anorexia subsided promptly on cessation of the injections, and the remaining period of observation passed without incident. The intense proteinuria exhibited by this man may have acted as a safety valve to prevent expansion of his plasma volume to the point where it would have precipitated cardiac failure.

Patient E. G. ran a stormy clinical course. On the third day of albumin she became febrile and during the last few days of injections, as well as

\section{EFFECT OF NTRANENOUS ALEUMN ON SERUM PROTEINS BLOOD VOLUME, HEMATOCRT AND ERYTHROCYTE SEDIMENTATION}

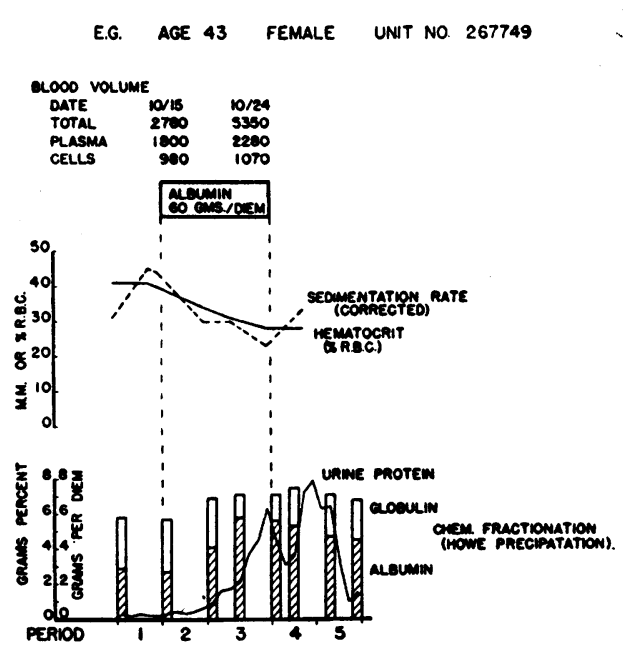

FIG. 6
EFFECT OF NTRAVENOUS ALBUNN ON SERUM PROTENS,
BLOOD VOLUME, HEMATOCRT AND ERYTHROCYTE SEDIMENTATION

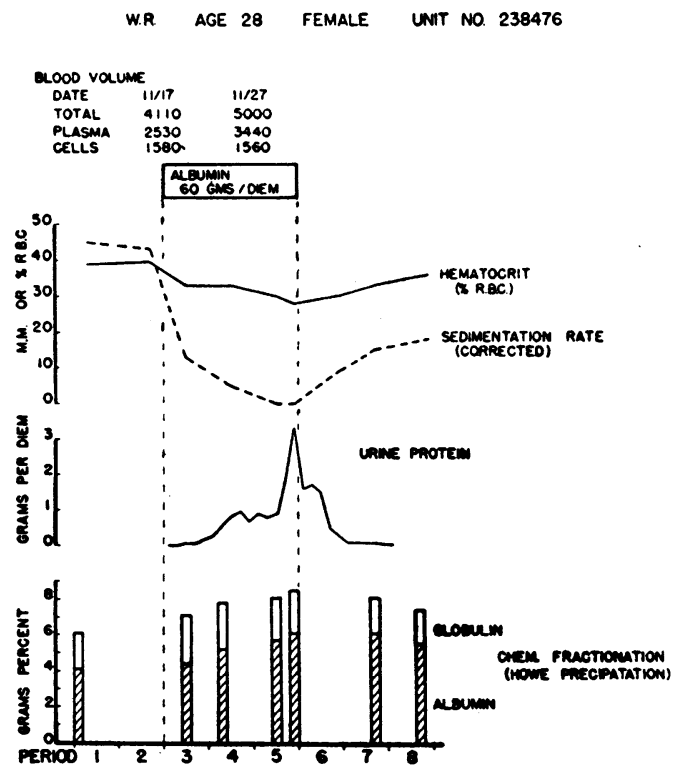

FIG. 7

in the post-control period, there was remittent fever, with spikes as high as $40^{\circ} \mathrm{C}$. A left peroneal palsy was observed on the fifth day, and on the sixth day edema became evident, which increased progressively throughout the rest of the experimental period. Small bilateral pleural effusions, which were present on admission, increased in size and a pericardial effusion was noted shortly after the patient returned to the general ward. Both the fever and the peripheral neuritis were felt to be part of her disease process. There seems little doubt, on the other hand, but that the edema, increasing pleural effusions, and the pericardial effusion were secondary to the administration of albumin. Obviously the remarkable gain of $5 \mathrm{~kg}$. in weight in 12 days was due to the increasing anasarca.

Patient W. R. was unaffected by the injections until the eighth day. At this time she complained of a feeling of fullness in the abdomen and loss of appetite. During the evening of the 11th day, she had an attack of nocturnal paroxysmal dyspnea and rales were heard at the bases of both lungs. Restriction of salt was enforced beginning with the 12th day, following which there was a 
prompt diuresis and a decrease in weight. Nevertheless, exertional dyspnea persisted and on occasion scattered rales were heard at the base of the right lung. Both symptoms and signs disappeared within two days after stopping the injections of albumin. It should be recalled that this patient had no evidence whatever of organic heart disease, and the syndrome of left ventricular failure appeared to be secondary to the increase in plasma volume, undoubtedly related to the intravenous administration of albumin.

Eugene G. received albumin intravenously for 15 days during periods 3 through 5 in the experiment. In period 4 the patient ran a low grade fever and had a mild diarrhea probably due to an intercurrent infection. During the last six days of the experimental period he too complained of a feeling of fullness in the abdomen, became anorexic, and vomited occasionally. It was difficult to evaluate his symptoms because of his exaggerated emotional responses and it was considered

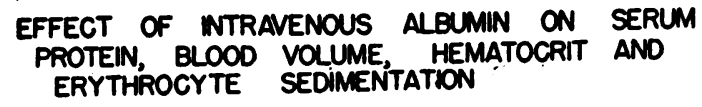

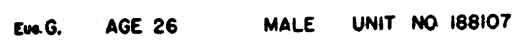

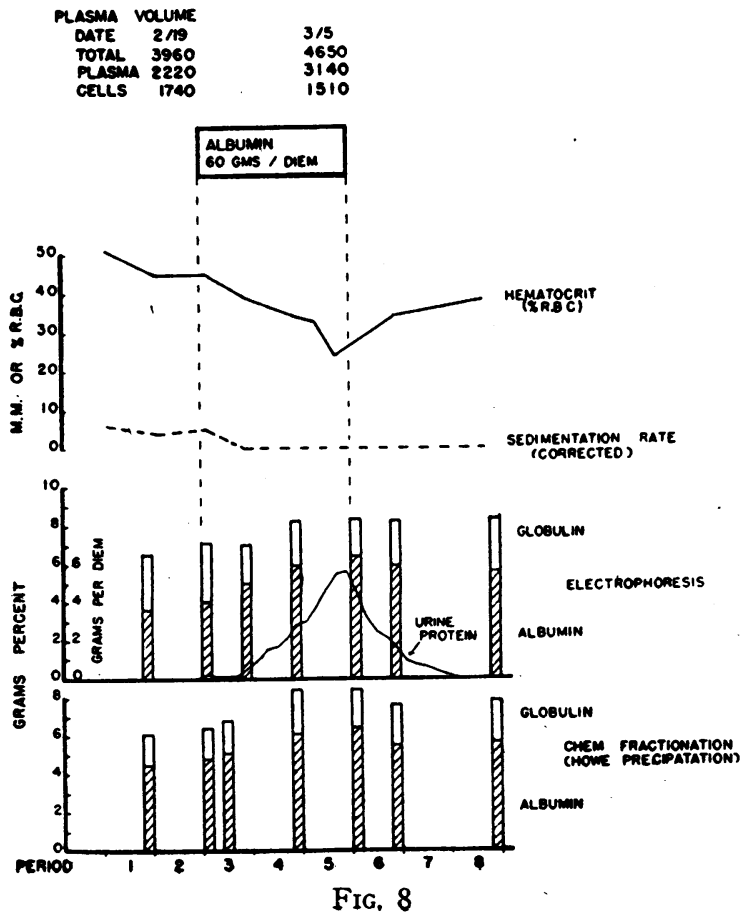

GALCIUM AND PHOSPHORUS BALANCES
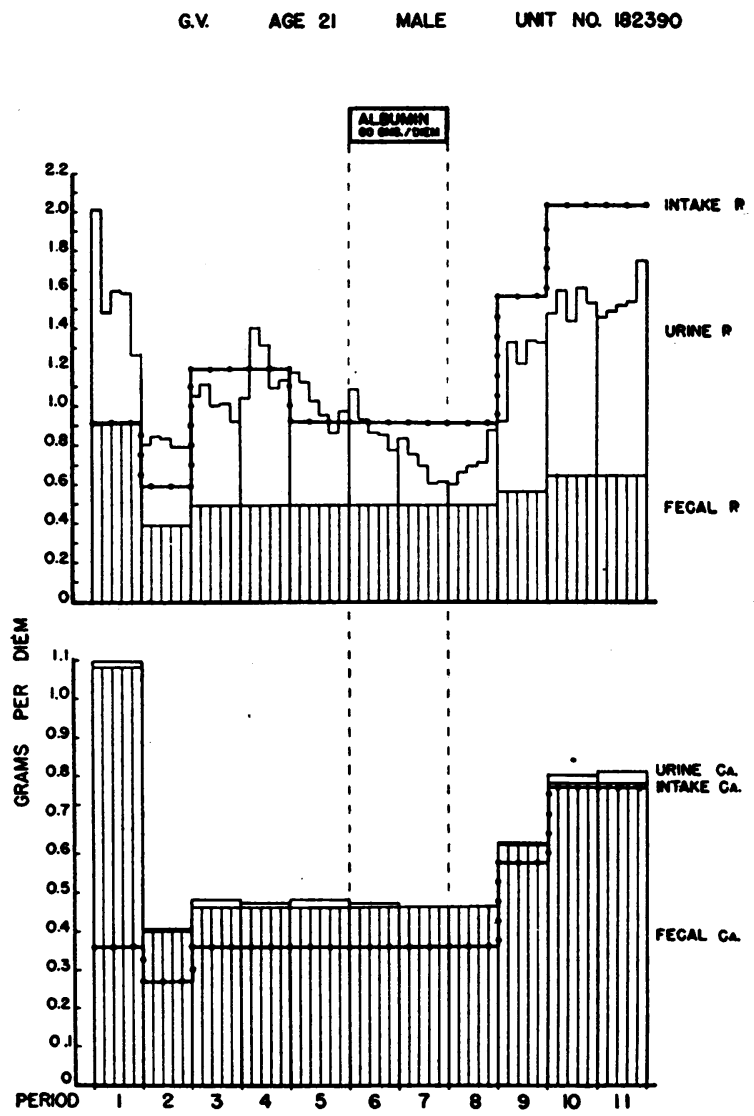

Fig. 9

Positive calcium and phosphorus balances are indicated by clear areas between intake line and the columns representing the sum of urinary and fecal excretions. An extension of these columns above the intake line denotes a negative balance.

improbable that albumin therapy was the chief basis of his discomfort. The objective effects were the gain in weight and the proteinuria which have been considered previously. Neither of these was of a magnitude to cause concern.

\section{Calcium and phosphorus balances}

Phosphorus balances were done on all patients primarily to estimate the amount of nitrogen which was released or bound in the catabolism or anabolism of tissue protein. This can be done only when the exchange of phosphorus with calcium is taken into consideration (23) and for this reason calcium balances were also carried out. The essential data are plotted in Figures 9-12. 


\section{CALCIUM AND PHOSPHORUS BALANCES}

E.G. AGE 43 FEMALE UNIT NO. 267749

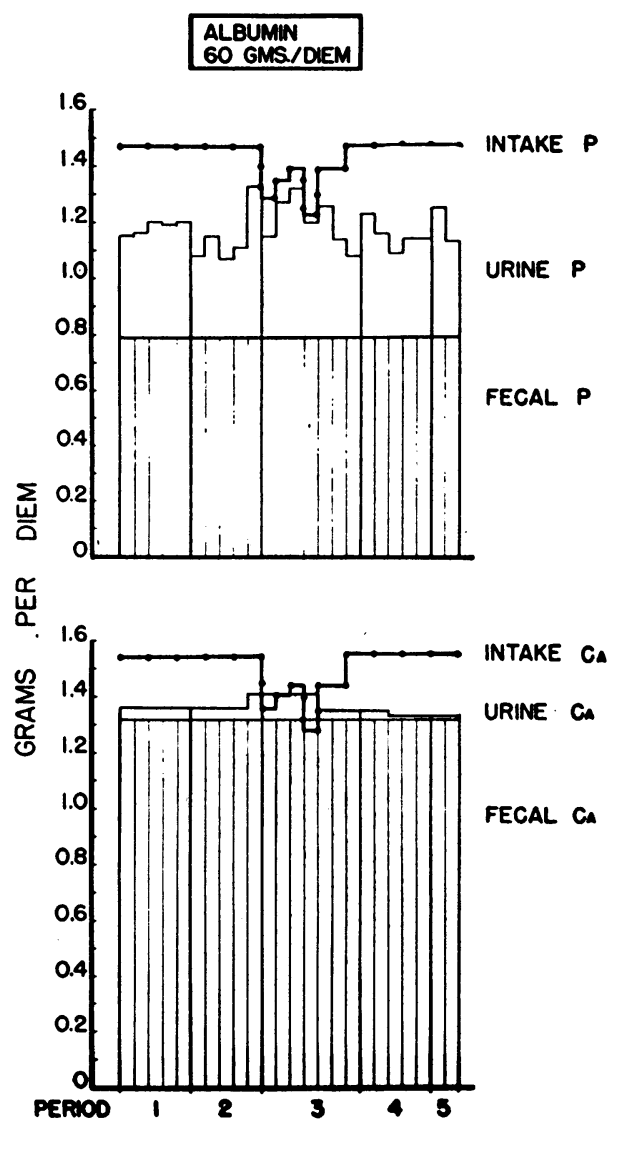

Fig. 10

For legend, see Figure 9.

Because of the dietary and other differences in the programs to which these patients were subjected, it will be necessary to include a brief description of each case.

The rheumatic patient, G. V., received an intake of phosphorus of $0.914 \mathrm{Gm}$. and calcium of 0.36 $\mathrm{Gm}$. daily during the control periods. The phosphorus intake was increased appreciably when the beef supplement was given, but was not increased materially by albumin which contains very little phosphorus. The phosphorus balance followed the expected course during the control periods and at the time when beefsteak was given (i.e., it correlated well with the nitrogen balance). In periods 6 and 7 when albumin was injected, one notes a gradual decrease in the excretion of uri- nary phosphorus; and this continued throughout the post-control period (period 8). Because of the low intake of calcium, the balance was negative and the excretion in the urine very low. In periods 7 and 8 , evidently as a consequence of the administration of albumin, calcium completely disappeared from the urine and its disappearance coincided with the lowest values of urinary phosphorus. An adequate diet was given in periods 9,10 , and 11 with retention of considerable nitrogen and phosphorus. Calcium was present again in the urine but the balance still remained slightly negative.

The calcium and phosphorus in the diet of E. G. were moderately high, 1.54 and $1.47 \mathrm{Gms}$. a day, respectively. Some of the irregularity in the intake (Figure 10) is the result of small losses through vomiting. Retention of both elements occurred in the control period. Injection of albumin did not produce much reduction in urinary phosphorus nor change in the phosphorus balance, a fact which constitutes the main argument in the

\section{CALCIUM AND PHOSPHORUS BALANCES}

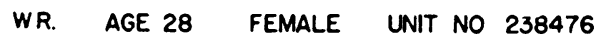

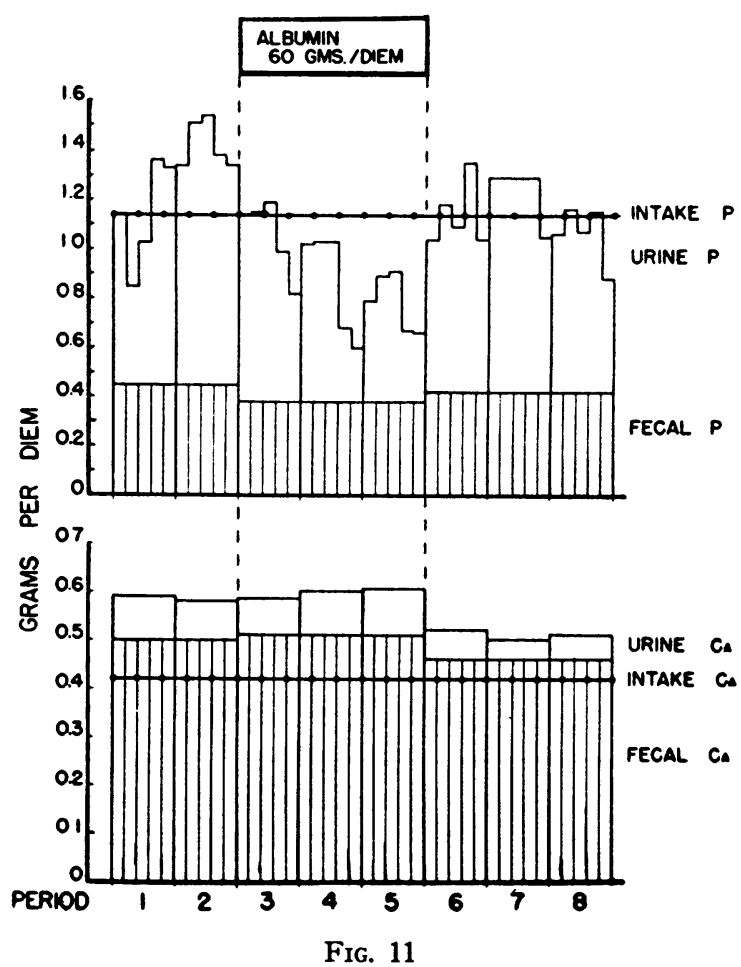

For legend, see Figure 9. 
CALCUM AND PHOSPHORUS BALANCES

Eug.G. AGE 26 MALE UNIT NO. 188107

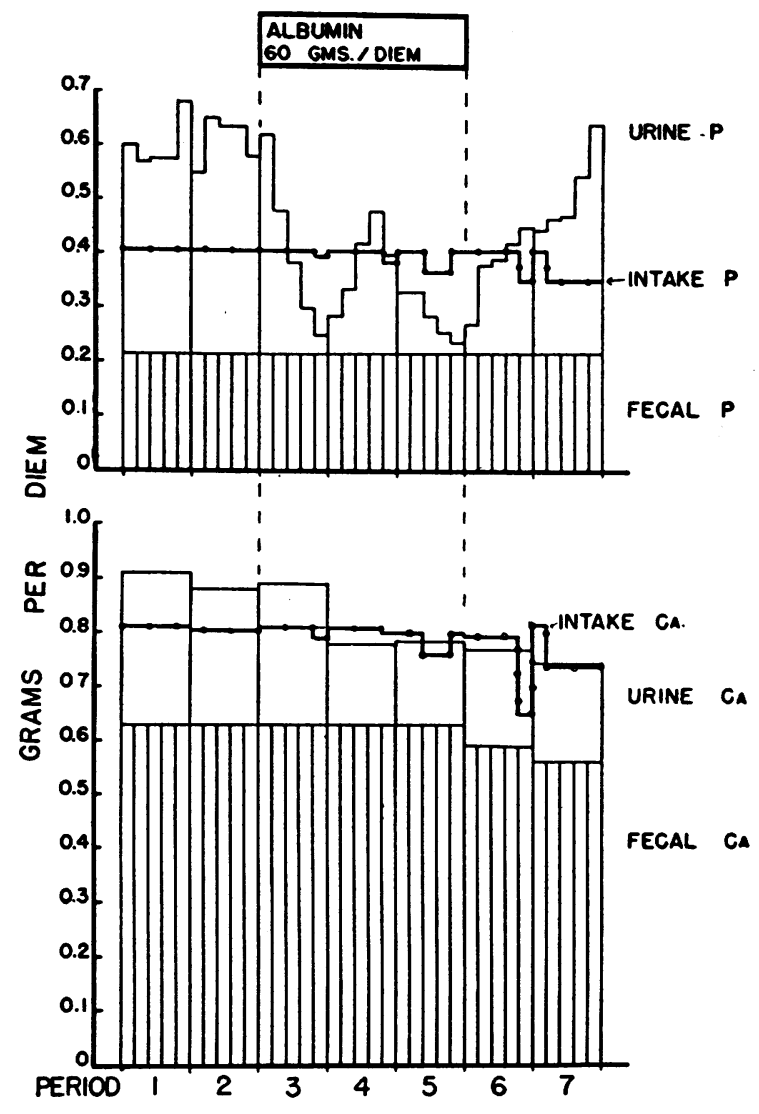

FIG. 12

For legend, see Figure 9.

contention that this patient was unable to convert more than a small portion of the injected protein into cellular protoplasm. The calcium of the urine became less in the experimental period. In the post-control period its excretion almost ceased.

The basic diet of W. R., who was in nearly normal health, corresponded rather closely to that of G. V. and was low in nitrogen and calcium but adequate in phosphorus and calories (Table I). Figure 11 shows the pronounced decrease in the urinary phosphorus and the positive phosphorus balance during the last ten days on albumin. The irregularity of the curve of urinary phosphorus is probably due to the fact that she received five different diets during the experimental period each of which contained the same amount of nitrogen, but differed somewhat in its content of cal- cium and phosphorus. As the method of continuous sampling was used for the analysis of her diets, the only analytical values obtained for intake were those for a five-day period. The negative calcium balance was not unexpected in view of the suboptimal intake of this element. It is to be noted that urinary calcium decreased in the post-albumin control period. We have then, in this patient, essentially a duplication of the results previously described in G. V.

On analysis of the diet of Eugene G., it was found to contain only $0.421 \mathrm{Gm}$. of phosphorus, which was less than had been anticipated. Since the experiment was already well under way when this was discovered, no supplementary phosphate was given. Calculations had shown the diet to be deficient in calcium, and the deficit in dietary calcium was made up by the administration of calcium gluconate in divided doses so that the daily intake was slightly in excess of $0.8 \mathrm{Gm}$. With the injection of albumin and in the postcontrol periods, urinary phosphorus decreased to very low levels. Fecal phosphorus, on the contrary, did not decrease. Because of the very low phosphorus intake, the balance was only slightly positive even at the time when the urinary excretion was minimal. The small rise in phosphorus excretion in period 4 coincides with an intercurrent infection when the patient was mildly febrile and had a few diarrheal stools. Although the intake of calcium should have been sufficient to maintain equilibrium, the balance was rather consistently negative. (This may have been due to the fact that the limited supply of available phosphorus was all used to meet the demand for conversion of albumin to cell protein, thus leaving little or no phosphorus to combine with the calcium.) However, the urinary calcium was affected as in the other patients and decreased in the second and third periods on albumin and in the post-albumin control period.

This consistent decrease in the urinary calcium is not without interest. Albright (13) has noted the association of decreased urinary calcium with intravenous administration of plasma protein. From the present studies, it seems to be of little importance in its effect on the overall calcium balance and correlates poorly with some of the other phenomena observed. It occurs whether or not there is a decrease in urinary phosphorus 
(data on E. G.) and does not relate directly to the proteinuria. Serum calcium was followed carefully in only one patient (Eugene G.) and in this instance it rose from a control value of $11.3 \mathrm{mg}$. per cent to $14.9 \mathrm{mg}$. per cent, coincidentally with the peak value for the concentration of serum protein. This appears to be an indication that calcium was bound to the albumin retained in the blood stream. Nevertheless, from the quantitative point of view, our data suggest a far greater actual retention (decreased urinary excretion) of calcium than was required by the extra albumin in circulation. It is true, of course, that we are unable to give an accounting for the albumin which has diffused into the lymph or extracellular fluid and which might be expected to bind calcium. That some of the injected albumin may be reconstituted in the form of calcifiable osteoid tissue is likewise a possibility (13).

\section{Actual versus "theoretical" nitrogen balance}

In the metabolism of protoplasm the exchanges of nitrogen must in the long run be associated with exchanges of phosphorus and potassium in amounts comparable to the proportion which exists in tissue, if normal structural relationships are to be maintained. The essential correctness of this thesis has been repeatedly demonstrated by Albright et al. (23-25) and constitutes the basis for the computation of the theoretical nitrogen balance. If one corrects the phosphorus balance for the amount combined with calcium, the remainder should give an index of the amount of nitrogen required in the anabolism and catabolism of tissue. In practice, during metabolic experiments, the actual nitrogen balance and the theoretical nitrogen balance are in fairly good agreement during the oral feeding of protein and in fasting.

In the preparations of Figures 13-16, both the actual and theoretical nitrogen balances have been plotted, not as deviations from control periods, but as they actually occurred. This makes very little difference except in the case of Eugene G., where the balance of phosphorus in preliminary periods was consistently and significantly negative.

\section{ACTUAL AND THEORETICAL NITROGEN BALANCE}

G.V. AGE 21 MALE UNIT NO. 182390

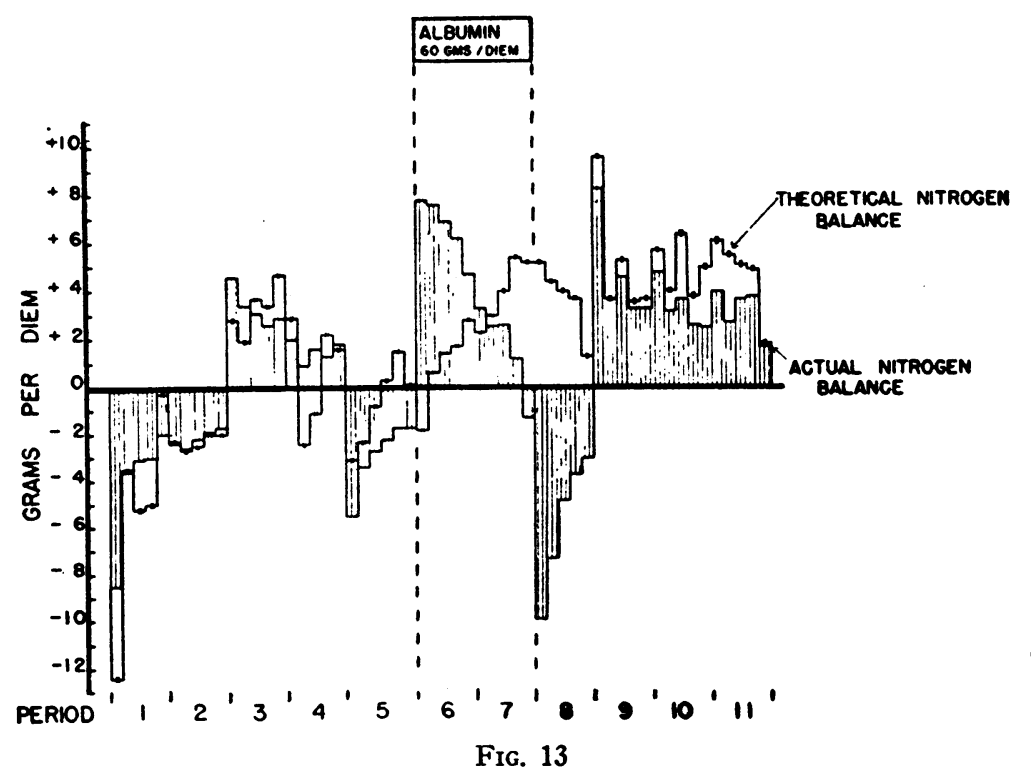

The actual nitrogen balance is represented by the lined columns, the theoretical nitrogen balance by the clear columns. When overlapping occurs, the borders of the theoretical nitrogen balance columns are demarcated by squares superimposed on the limiting lines. 
ACTUAL AND THEORETICAL NTROGEN BALANCE

E.G. AGE 43 FEMALE UNT NO. 267749

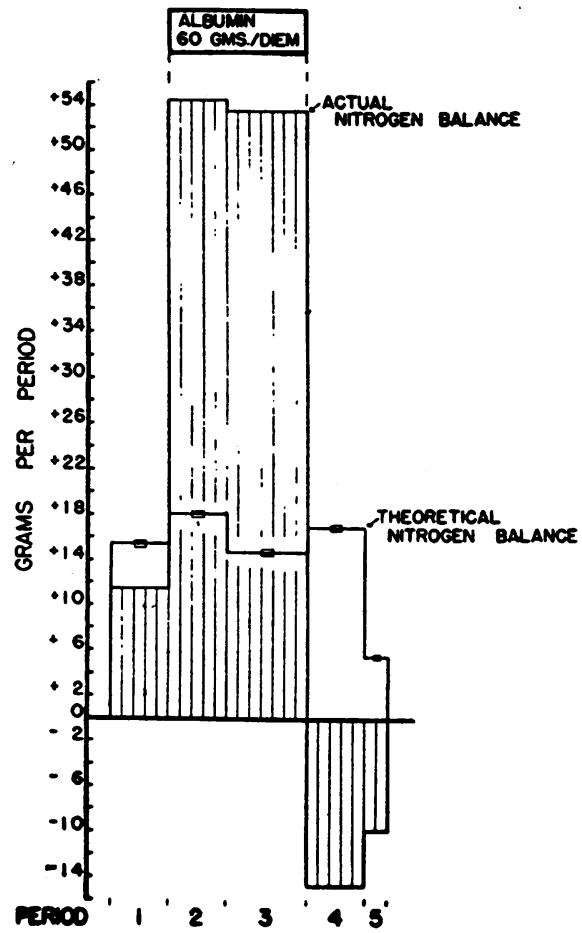

FIG. 14

For legend, see Figure 13.

In G. V. the actual and theoretical balances of nitrogen agreed fairly well until albumin was given. During these two periods the theoretical balance was at first much less positive than the actual balance, and in the post-albumin period it remained strongly positive although the actual balance had become negative (Figure 13).

The actual nitrogen balance of $\mathrm{E}$. G. was markedly positive throughout the administration of albumin, but the theoretical balance was small and did not increase in the stepwise fashion observed in the other patients (Figure 14), a circumstance which will receive further comment presently.

The data on W. R. (Figure 15) are quite similar to those on G. V. and show a progressive increase in the "theoretical" retention of nitrogen during the 15 days on albumin. The theoretical balance differs from G. V., however, in that it did not continue to be strongly positive in the post-albumin period.
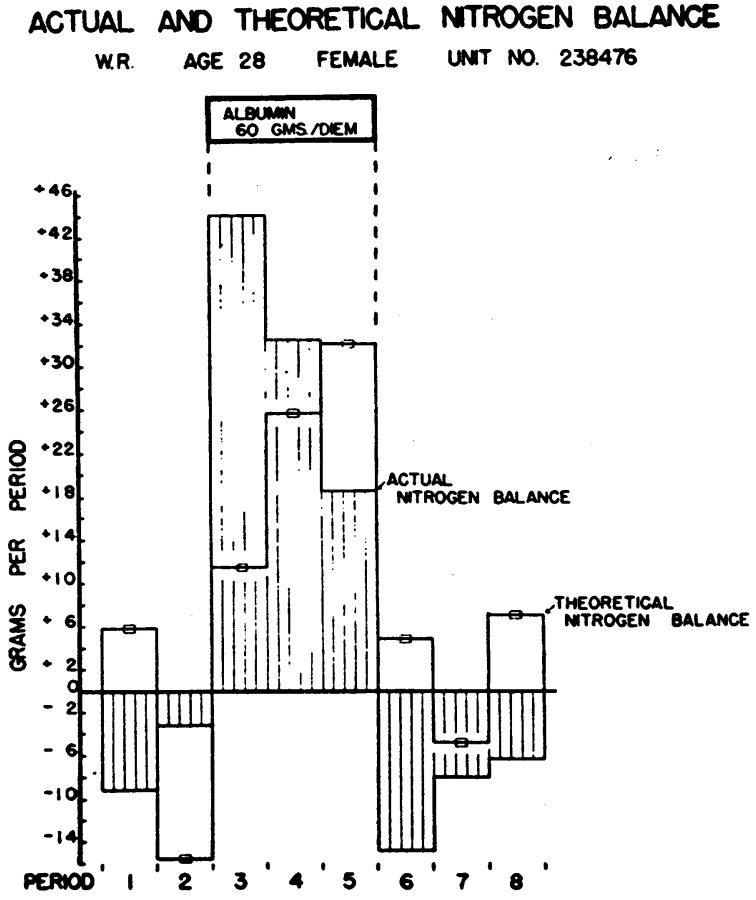

Fig. 15

For legend, see Figure 13.

ACTUAL AND THEORETICAL NITROGEN BALANCE EUG. G. AGE 26 MALE UNIT NO 188107

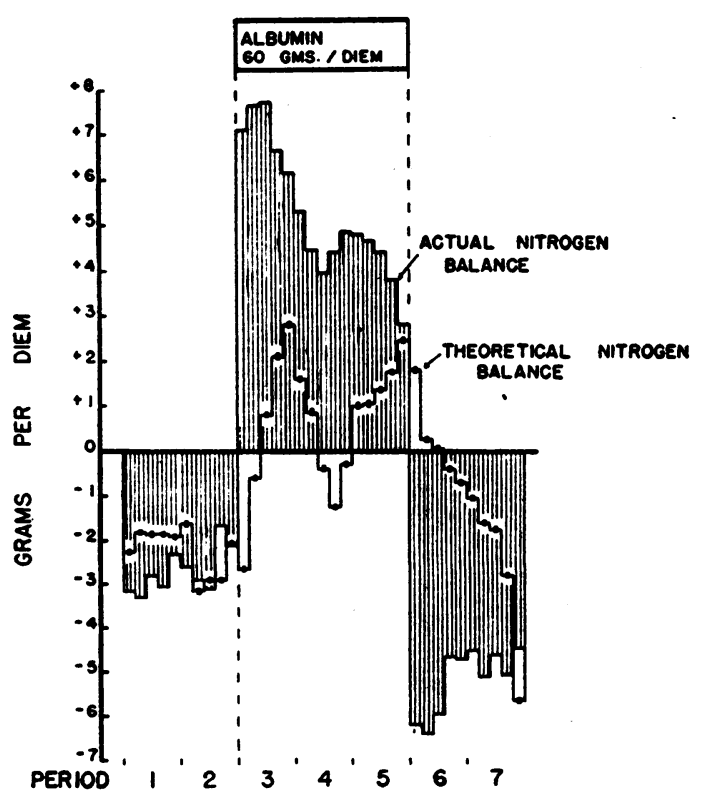

Fig. 16

For legend, see Figure 13. 
The general trend of events in subject Eugene G. (Figure 16) was similar to that in G. V. and W. R., but one notes that the theoretical nitrogen balance is only slightly positive during albumin injections when computed from phosphorus accruing to the body. On the other hand, when calculated from the deviation of the phosphorus balance from that of the preliminary control periods, the theoretical balance of nitrogen is almost as great as in the other two patients. We have commented previously on the almost complete disappearance of phosphorus from the urine of this man as the administration of albumin was continued. This suggests that the phosphorus derived from endogenous sources, instead of being excreted as in the control period, was being reutilized. It is to be noted further that his intake of phosphorus was low and that there may have been an obligatory excretion of phosphorus in the feces, for the latter did not decrease even when the demand for phosphorus seems to have been marked. Thus, the whole trend of his response may have been altered by the limited quantity of available phosphorus.

\section{The fate of the injected protein}

We have used the "theoretical" nitrogen balance, as, has Albright $(13,23)$, to estimate the conversion of phosphorus-poor albumin into cel-

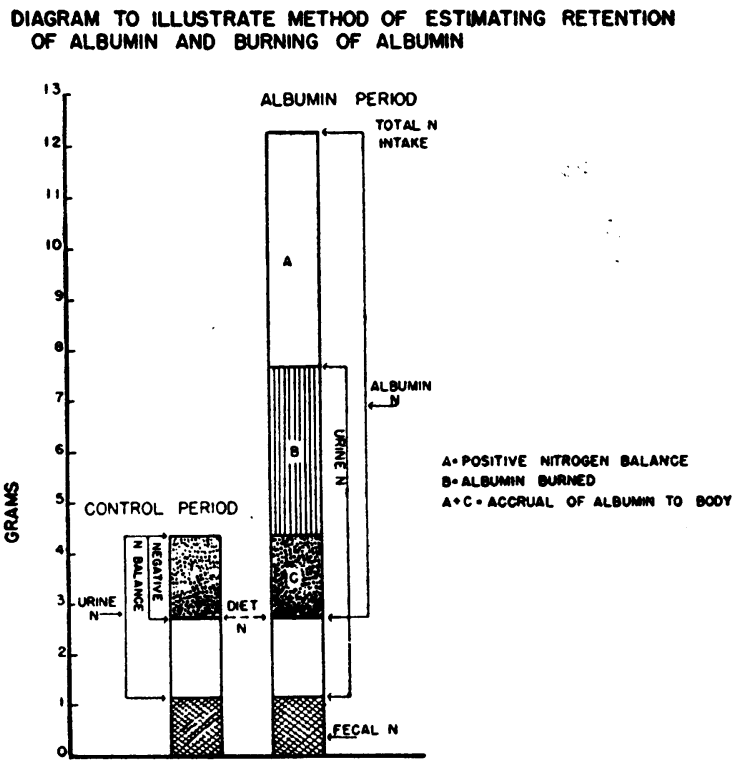

FIG. 17
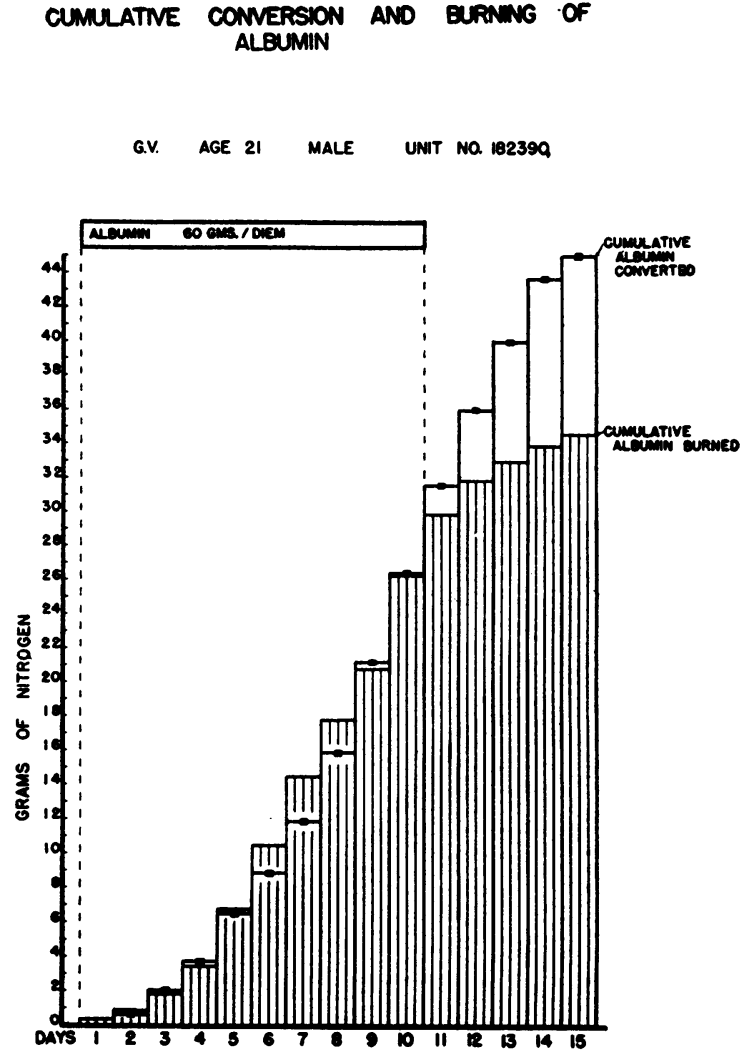

FIG. 18

Chart construction is such that the column for day 15 gives the sum of the metabolic effects from day 1 up to that moment.

The cumulative albumin burned is represented by lined columns; the cumulative albumin converted, by the total height of the clear columns.

When overlapping occurs, the limiting borders of the clear columns are demarcated by lines with squares superimposed on them.

lular protein associated with the average amount of phosphorus. The fraction of the injected albumin which has been catabolized (deaminated) may be estimated from the rise in the excretion of the urinary nitrogen above the baseline of the control periods. The fraction of the unchanged albumin wasted by excretion in the urine can readily be measured also. With this information at hand, a balance sheet can be drawn up which shows in a general way what has happened to the albumin at any moment in the experiment. The injected albumin can be roughly accounted for as follows :

(a) Albumin catabolized.

(b) Albumin converted to tissue protein. 
(c) Albumin remaining in the blood stream, extracellular fluid, etc.

(d) Albumin excreted in the urine.

There are obvious limitations to these calculations. For example, one cannot tell whether albumin is converted to tissue protein and then catabolized, or whether it is directly degraded, nor can one follow the fate of the carbon residues of the deaminated protein. The exact location of albumin apparently retained as such in the body is not known except for that part remaining in the plasma.

In setting up the balances two main assumptions were made: (1) that the exchange of nitro-

\section{CUMULATIVE RETENTION AND CONVERSON OF ALBUMN TO TISSUE (?) PROTEN}

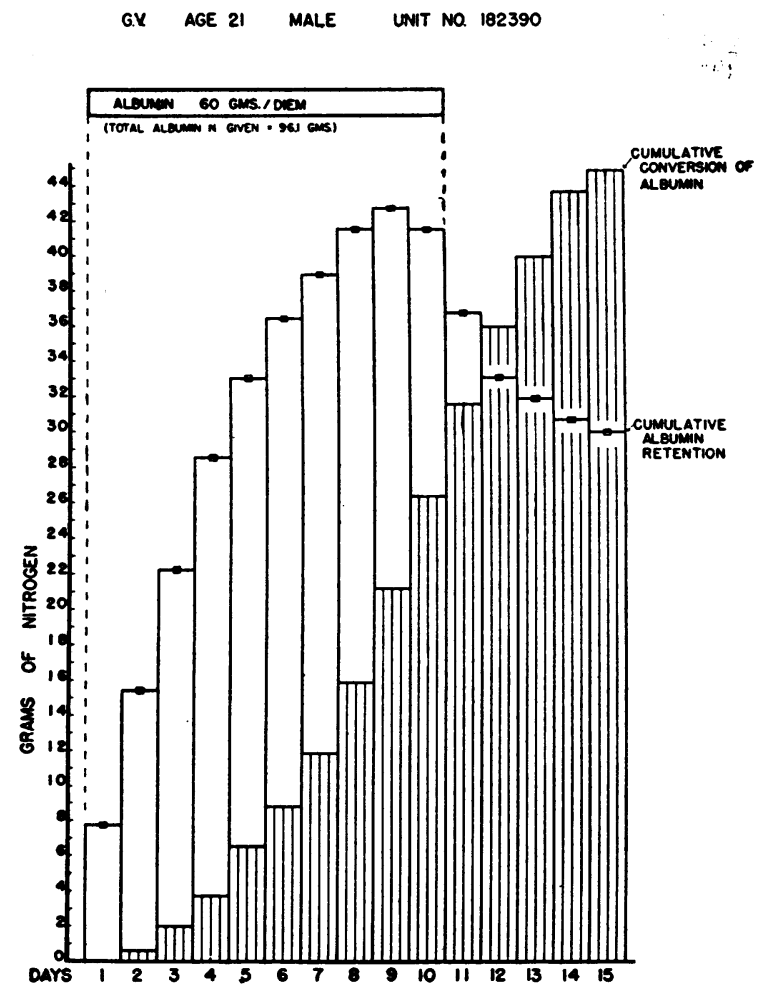

Fig. 19

Chart construction is such that the column for day 15 gives the sum of the metabolic effects from day 1 up to that moment.

The cumulative albumin converted is represented by lined columns; the cumulative albumin retained, by the total height of the clear columns, from the baseline to the lines with squares superimposed on them.
CUMLATIVE BURNNG AND CONVERSION OF ALBUMN

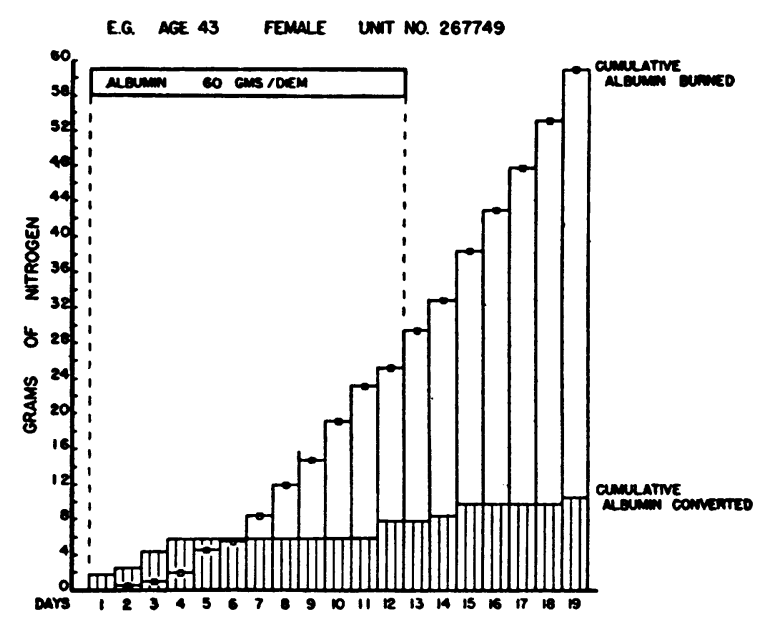

FIG. 20

The cumulative albumin converted is represented by lined columns; the cumulative albumin burned, by the total height of the clear columns from the baseline to the lines with squares superimposed on them.

gen, phosphorus and calcium as measured on the final days of the control period would have remained constant throughout the experiment, had albumin not been administered; (2) deviations from the baseline of the control period could be ascribed to the albumin injections. Figure 17 has been constructed to illustrate the principles involved. The data are those obtained on G. V. The basic intake of nitrogen failed to meet the endogenous requirement of this patient, and he was in slightly negative balance during the foreperiod. When albumin was given, there was an increase in the urinary nitrogen above the basic excretion of the foreperiod. This represents albumin deaminated (burned). The gross retention of albumin in the body is the difference between that injected and that deaminated. The albumin retained is, therefore, greater than the actual positive nitrogen balance by this method of computation.

The cumulative burning of albumin in comparison with the amount converted to tissue protein in the case of G. V. has been graphed in Figure 18. One notes that neither process occurs to a significant degree until the third day of albumin injections. Thereafter both processes increased in stepwise fashion and continued even during the post-control period. The cumulative reten- 
tion and conversion of albumin for this patient is depicted in Figure 19. There are two main points of interest, the delay in the conversion of
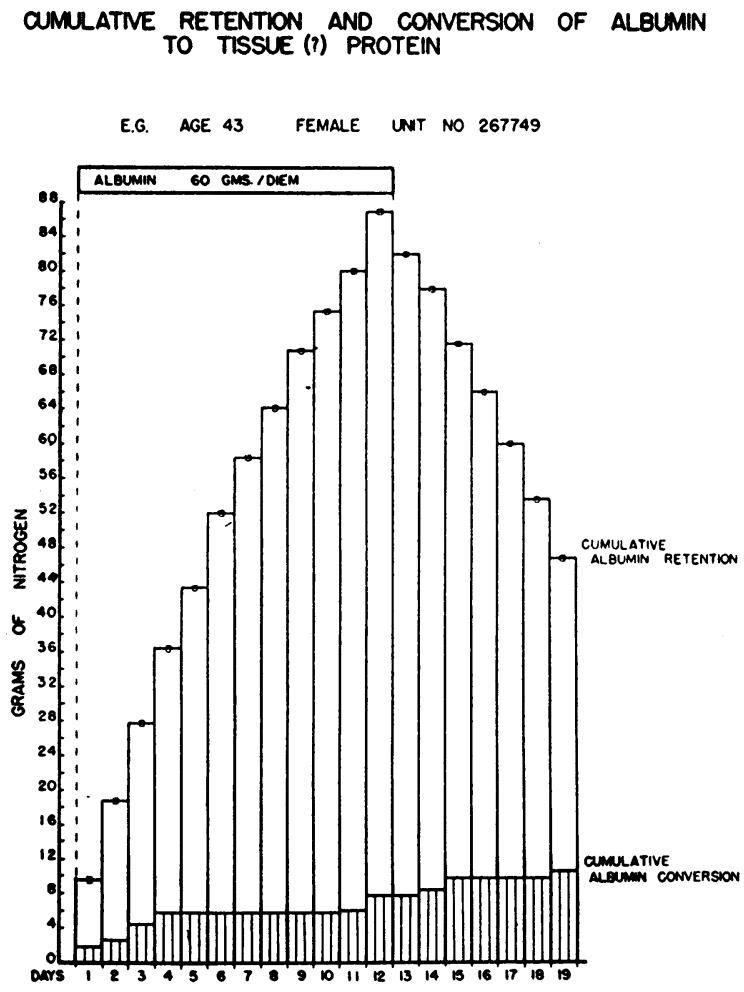

FIG. 21

For legend, see Figure 19. the retained albumin, and the apparent conversion of more albumin than was retained at the end of the control period. There are perhaps two possible explanations for the latter anomalous situation: (1) an error in the calcium-phosphorus balance which made the retention of the phosphorus appear greater than it actually was; (2) utilization of a small amount of the phosphorus for some other purpose than the conversion of albumin to tissue protein.

Figures 20 and 21 which record the cumulative conversion and burning, and cumulative retention

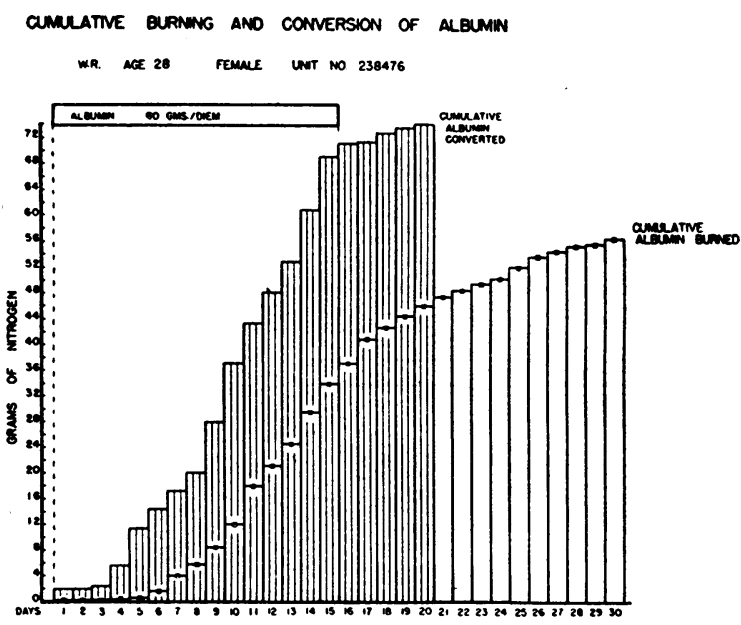

FIG. 22

For legend, see Figure 20.

CUMULATIVE RETENTION AND CONVERSION OF ALBUMIN TO TISSUE (?) PROTEIN

W.R. AGE 28 FEMALE UNIT NO 238476.

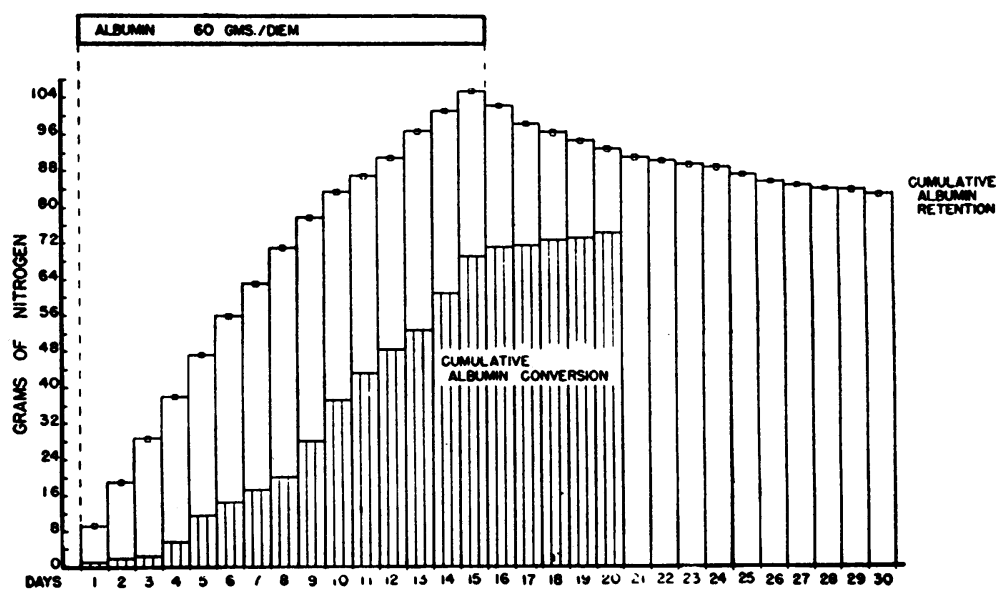

FIG. 23

For legend, see Figure 19. 


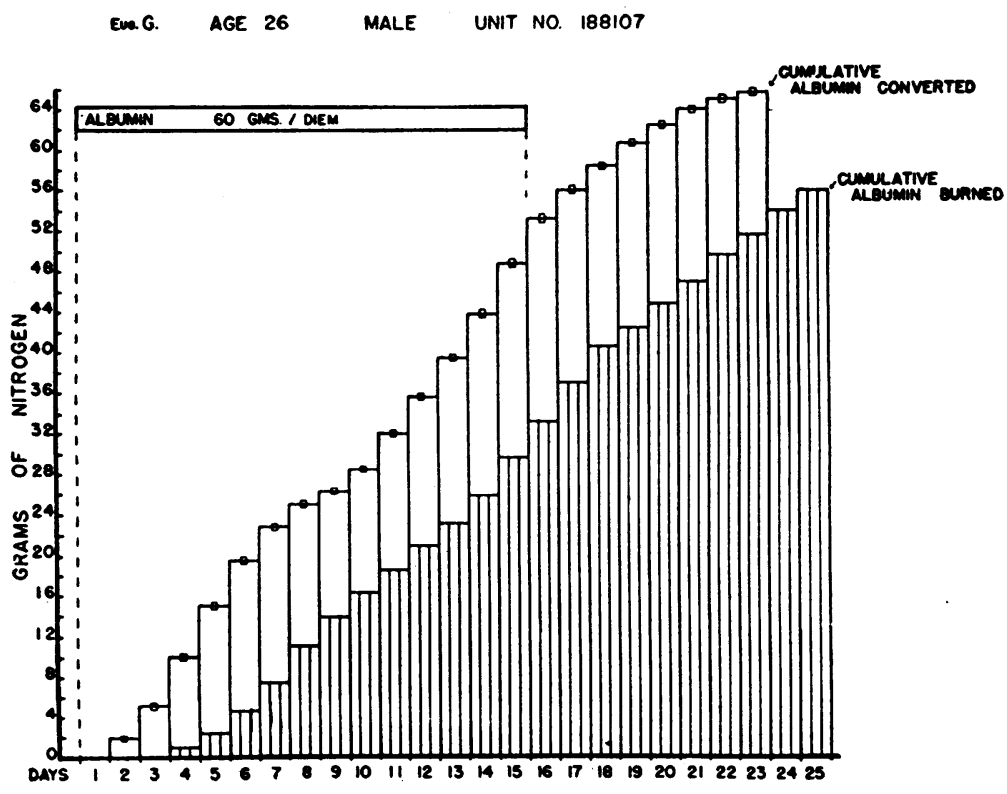

FIG. 24

For legend, see Figure 18.

and conversion of albumin, respectively, by $E$. G. should be contrasted with those of G. V. In E. G. deamination proceeded in somewhat the same fashion, but to a greater degree and the amount of albumin converted to cell protein was very small. Even at the end of the post-control period, a large percentage of it remained unchanged in the body. Figures 22 and 23 show the same processes in patient W. R. The deamination began slowly, while conversion was somewhat more rapid and did not appear to continue beyond the fifth post-control day. Figures 24 and 25 prepared from the data on Eugene G. are similar. Evidence of conversion could no longer be obtained after the seventh post-albumin day. The catabolism occurred more slowly, and the urinary nitrogen was still above the prealbumin level ten days after the injections were discontinued. About 50 per cent of the injected protein was incorporated into cell protein if one computes this fraction from the deviation of the phosphorus balance from the initial control periods.

The amount of albumin retained in the plasma of the individual patients at different times is presented in Table II. Inasmuch as these values are admittedly rough estimates, no definite con-

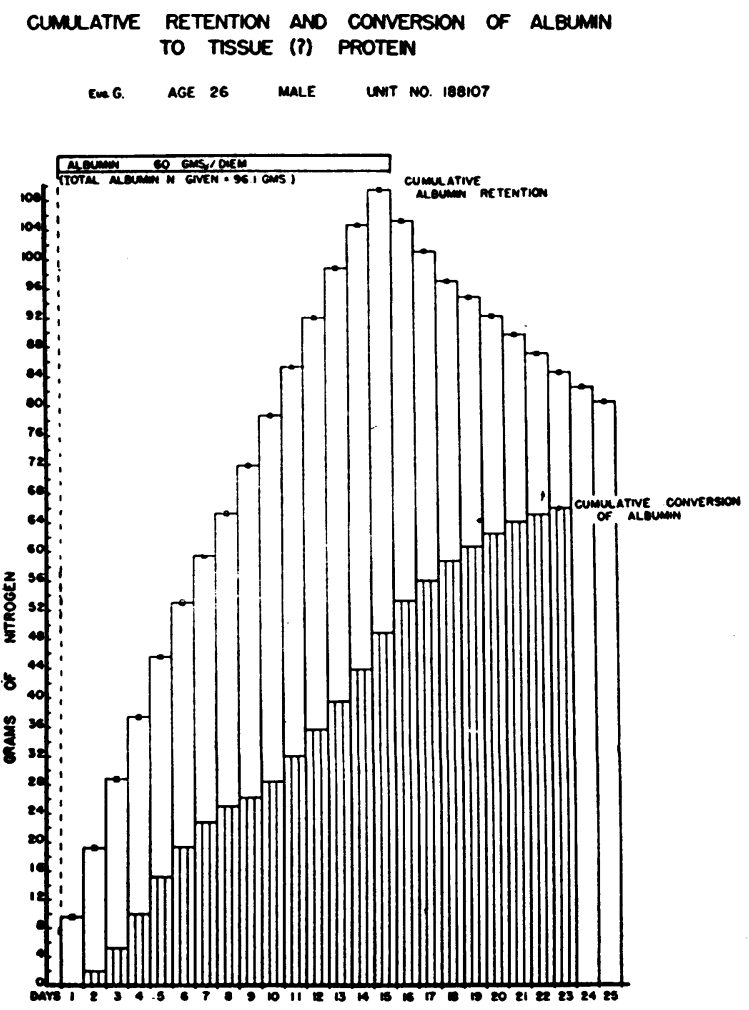

FIG. 25

For legend, see Figure 19. 
TABLE II

Albumin retained in plasma

\begin{tabular}{l|r|r|r|r}
\hline Subject & $\begin{array}{c}\text { Day of } \\
\text { experi- } \\
\text { ment }\end{array}$ & $\begin{array}{c}\text { Dose to } \\
\text { date }\end{array}$ & $\begin{array}{c}\text { Extra } \\
\text { amount } \\
\text { in plasma }\end{array}$ & $\begin{array}{c}\text { As } \\
\text { per cent } \\
\text { total }\end{array}$ \\
\hline & 6 & Gms. & Gms. & Gms. \\
G. V. & 9 & 540 & 184 & 26 \\
& 15 & 540 & 65 & 12 \\
E. G. & 5 & 300 & 43 & 14 \\
& 8 & 480 & 93 & 19 \\
& 12 & 720 & 117 & 16 \\
W. R. & 15 & 720 & 108 & 15 \\
& 3 & 180 & 40 & 22 \\
& 12 & 720 & 112 & 16 \\
& 14 & 825 & 154 & 19 \\
& 23 & 885 & 96 & 11 \\
& 4 & 240 & 45 & 19 \\
& 9 & 540 & 94 & 17 \\
& 15 & 900 & 213 & 24 \\
& 19 & 900 & 93 & 10 \\
& 23 & 900 & 58 & 6 \\
\hline
\end{tabular}

Note: Many of the calculations of plasma volume were made from changes in the hematocrit alone, according to the formula $P V_{2}=P V_{1} \frac{\left(H_{1}\right)\left(100-H_{2}\right)}{\left(100-H_{1}\right)\left(H_{2}\right)}$. Because of the known inaccuracies of venous hematocrit determinations, these figures are assumed to be rough estimates.

clusions will be drawn. However, it was our impression that the albumin seemed to leave the blood stream most rapidly in G. V. who had the smallest dose and the most pronounced proteinuria and least rapidly in E. G. who utilized it poorly. In no instance were observations continued long enough for all the extra albumin to have disappeared.

A summary of the fate of the albumin administered to these patients is given in Table III. The large excretion of urinary protein in G. V. and the comparatively small conversion of albu-

TABLE III

Summary of albumin administration

(As per cent of the amount given)

\begin{tabular}{|c|c|c|c|c|}
\hline \multirow{2}{*}{ Subject } & \multicolumn{2}{|c|}{ Male } & \multicolumn{2}{|c|}{ Female } \\
\hline & G. V. & $\begin{array}{c}\text { Eugene } \\
\text { G. }\end{array}$ & E. G. & W. $\mathbf{R}$. \\
\hline $\begin{array}{l}\text { Albumin burned } \\
\text { Albumin excreted in urine } \\
\text { Albumin retained in body }\end{array}$ & $\begin{array}{l}35.9 \\
26.6 \\
37.5\end{array}$ & $\begin{array}{r}39.0 \\
5.3 \\
55.7\end{array}$ & $\begin{array}{r}51.2 \\
8.3 \\
40.5\end{array}$ & $\begin{array}{r}39.9 \\
1.6 \\
58.5\end{array}$ \\
\hline $\begin{array}{l}\text { Albumin converted to tissue } \\
\text { protein }\end{array}$ & $\begin{array}{r}100.0 \\
46.6\end{array}$ & $\begin{array}{r}100.0 \\
45.6\end{array}$ & $\begin{array}{r}100.0 \\
9.2\end{array}$ & $\begin{array}{r}100.0 \\
52.4\end{array}$ \\
\hline
\end{tabular}

min to tissue protein in E. G. are emphasized again. W. R. and Eugene G., who were essentially normal, reacted to the injections with remarkable similarity.

\section{DISCUSSION}

The clinical response to human serum albumin given intravenously depends not only on its nutritive properties as a protein, but also on two other factors, namely, its potent osmotic activity and its nativity to the human body. Probably because of the last-named factor it is metabolized comparatively slowly under normal circumstances. Therefore, when the substance is given in large quantities, its slow utilization results in the accumulation of significant amounts of osmotically active protein. Thus to predict the response of the individual to injections of human albumin, one should take into consideration $(a)$ his state of nutrition, especially with respect to protein, (b) the permeability of the capillaries in general and of the glomerulus in particular, and (c) the status of the cardiac reserve. Once an individual is saturated with albumin the compensatory adjustments may break down and proteinuria, cardiac decompensation, or edema may occur. Each of our four patients reacted differently to similar daily doses of intravenous albumin, and the importance of pre-existing disease (E. G.), renal permeability to protein (G. V.), dietary intake (E. G. and Eugene G.) and cardiac reserve (W. R.) are clearly shown.

The nutritive response as determined by the nitrogen balance deserves some comment even though this has been well described by other authors $(12,26)$. A positive nitrogen balance was present in all our patients at all times during the administration of albumin with the one exception of G. V. at a time when proteinuria was excessive. This exception should perhaps be emphasized since it is perfectly clear that the escape of albumin in the urine may reverse the nitrogen balance at a time when the need for protein still exists and the patient is still capable of storing considerable amounts of nitrogen. Moreover, the significance of the positive nitrogen balance should be determined in the light of the following facts. There is abundant evidence that plasma proteins will pass certain membranous barriers $(27,28)$. Albumin given intravenously 
escapes through the capillary walls into the lymphatic spaces and to a smaller extent into the interstitial spaces. The accumulation of the whole protein in plasma, lymph, and the interstitial fluid has been described by Riegel (26) as a metabolic dead space and this is true in the sense that the nitrogen retained in the acute experiment has not all been converted into cellular protein. Thus under only one condition could the positive nitrogen balance be used as an indication of the nutritive value of this protein; namely, when an accurate calculation of the unchanged albumin in the body is at all times available. The amount retained in the plasma can be determined comparatively easily by plasma volume and serum protein determinations, but the quantity held outside the plasma would require measurement of the concentration of the albumin in the extracellular fluid as well as the volume of the latter. Indirect calculations of the unchanged albumin from data such as ours are perhaps possible but can be done only if other balances (calcium, phosphorus and potassium) are carried out.

The mode, extent and determining factors of utilization of parenterally administered plasma protein has been of considerable interest both to us and to other investigators. If one accepts the hypothesis that retention of phosphorus with albumin is a sign that the latter is being converted to cell protein, it seems certain that many patients will be able to effect such a modification. Three of our four patients showed evidence of conversion. The failure of our fourth patient, E. G., certain postoperative patients (26), and one normal patient who was receiving only $37.5 \mathrm{Gms}$. of protein a day (29) to show evidence of significant utilization may be taken as evidence that albumin is subject to the general laws of protein metabolism in the body.

The efficacy of albumin in relation to food protein was studied in only one patient, G. V. Beef protein orally and albumin intravenously were compared in quantities containing nearly equal amounts of nitrogen. The total conversion of albumin to cell protein by our method of estimation was 46 per cent, that for beef protein 22 per cent. It is obvious that no conclusions can be drawn from a single trial of this nature.
The actual mode of utilization of parenteral plasma protein has been discussed by several groups of workers. Whipple and his associates (28) have postulated "fluid interchange between the reserve stores and organ cells in which the protein is produced, modified and utilized in the body economy." Such a give and take might be accomplished without breaking the protein into its constituent amino acids. An alternate explanation is offered by Eckhardt (12) who suggests that the process is one of gradual decay, and that only as the protein is split into its individual components does it become available to the cells. According to this hypothesis albumin introduced into the blood stream would be broken down slowly by proteolytic enzymes and those constituents not of immediate use for resynthesis of protein would be deaminated and excreted. By observing the rate at which injected albumin disappeared from the plasma, he was able to fit his data to a standard decay curve with a 50 per cent disappearance time in five days. Justification for neglecting the albumin held in extracellular fluid and lymph is based on the assumption that the proteins in these systems are in equilibrium with the plasma, although not necessarily of equal concentration. Thus when one measures the disappearance from the blood, one also measures the rate of disappearance from the extravascular spaces.

We were unable to establish similar decay curves in our patients because of too infrequent determinations of plasma volume. Decay in the sense used by Eckhardt would in our patients include albumin burned and converted, if one neglects the albumin lost in the urine. We have computed decay in our subjects using a time of five days for 50 per cent disappearance. Specifically this means that we have assumed that by the end of a five-day period, 50 per cent of the injected albumin would no longer be present as such in the body, but would have been either degraded or converted to cell protein. The values obtained for decay are compared with the sum of burning and conversion in Table IV and are expressed cumulatively as grams of nitrogen. The formula used for computing decay is that given for a series of daily injections (12). One sees fair correlation in the three patients, G. V., W. R., and Eugene G. This positive correlation we be- 
TABLE IV

Calculated decay of albumin vs sum of albumin catabolized and converted

\begin{tabular}{|c|c|c|c|c|c|c|c|c|}
\hline \multirow[b]{2}{*}{ Subject } & \multicolumn{2}{|c|}{ G. V. } & \multicolumn{2}{|c|}{ E. G. } & \multicolumn{2}{|c|}{ W. R. } & \multicolumn{2}{|c|}{ Eugene G. } \\
\hline & $\begin{array}{c}\text { Calculated } \\
\text { decay }\end{array}$ & $\begin{array}{c}\text { Sum of } \\
\text { catabolism } \\
\text { and } \\
\text { conversion }\end{array}$ & $\begin{array}{c}\text { Calculated } \\
\text { decay }\end{array}$ & $\begin{array}{c}\text { Sum of } \\
\text { catabolism } \\
\text { and } \\
\text { conversion }\end{array}$ & $\begin{array}{c}\text { Calculated } \\
\text { decay }\end{array}$ & $\begin{array}{c}\text { Sum of } \\
\text { catabolism } \\
\text { and } \\
\text { conversion }\end{array}$ & $\begin{array}{l}\text { Calculated } \\
\text { decay }\end{array}$ & $\begin{array}{l}\text { Sum of } \\
\text { catabolism } \\
\text { and } \\
\text { conversion }\end{array}$ \\
\hline $\begin{array}{r}5 \text { days } \\
10 \text { days } \\
15 \text { days } \\
20 \text { days } \\
25 \text { days }\end{array}$ & $\begin{array}{l}15.7^{*} \\
47.5 \\
72\end{array}$ & $\begin{array}{l}13 \dagger \\
52 \\
80\end{array}$ & $\begin{array}{l}15.7^{*} \\
47.5 \\
90.5 \\
95.5\end{array}$ & $\begin{array}{l}11 \dagger \\
25 \\
48 \\
72\end{array}$ & $\begin{array}{l}15.7^{*} \\
47.5 \\
87.5 \\
116 \\
130\end{array}$ & $\begin{array}{c}12 \dagger \\
42 \\
102 \\
119 \\
126\end{array}$ & $\begin{array}{l}15.7^{*} \\
47.5 \\
87.5 \\
116 \\
130\end{array}$ & $\begin{array}{c}17.6 \dagger \\
45 \\
78 \\
107 \\
121\end{array}$ \\
\hline
\end{tabular}

* Values in this column refer to the per cent of decay that had taken place by the 5th, 10th, 15th day, etc.

$\uparrow$ Values in this column refer to the sum of catabolism plus conversion also expressed as per cent of the amount of albumin received by the patient up to and including the $5 \mathrm{th}, 10 \mathrm{th}$, and $15 \mathrm{th}$ days respectively.

lieve adds further support to the use of the theoretical nitrogen balance as a means of determining the conversion of albumin to some other form of protein. It is also clear that the rate at which a standard dose of albumin is metabolized is closely similar in these three individuals.

The poor correlation in E. G. is in agreement with our other data which indicate that a considerable fraction of the injected albumin remained as such presumably in edema fluid. Partial confirmation of this is found in the fact that the protein concentration of the pleural fluid was 6.2 Gms. per cent. It seems reasonable that excessive quantities of albumin leaked into the interstitial fluid in this patient, possibly because of increased capillary permeability. However, it does not seem likely that stagnation of the protein in the extracellular spaces was purely on a mechanical basis for if conversion of the albumin to cell protein and hence its removal from interstitial fluid depends upon contact with cells bordering on extravascular spaces, there should have been no lack of opportunity for this to occur. One must not overlook a possible influence of diet which was perhaps critically low in calories (Section I). The synthesis of protein in the cells may have been nearly maximal before the albumin was given, and further increase was prevented by a lack of source of energy.

The mechanism of the proteinuria, which eventually occurred in all our patients, requires brief comment. In no case was there suspicion of serious renal damage, since values for glomerular filtration rate and renal plasma flow were within normal range. This does not, however, rule out the possibility of abnormal glomerular permeability, especially in G. V. who had traces of protein in his urine prior to albumin injections. It might be argued $(a)$ that injections of albumin damage the glomeruli and that leakage of protein is permitted. A previously damaged glomerulus would perhaps leak more protein than one which was formerly normal. (b) That the normal glomerulus permits the passage of small amounts of protein which is ordinarily recaptured by the tubular cells and that proteinuria after albumin is secondary to the high concentration of albumin in the plasma and is due to filtration of more albumin than can be reabsorbed by the tubular cells. In view of the recent observations of Monk and Yuile (30), Terry et al. (31), and Rather (32) and the arguments advanced by them, the second mechanism appears to fit the facts better than the theory of damage. As was the case in animal experiments (31), the albuminuria of our patients ceased soon after the injections were stopped and tests of kidney function showed no decrease as a result of the procedure.

\section{SUMMARY}

Each of four subjects received a daily dose of $60 \mathrm{Gms}$. of concentrated sodium-free albumin for ten or more days. Balances of nitrogen, calcium, phosphorus, and potassium were made during control, albumin, and post-albumin periods. Concomitant observations of serum protein fractions, plasma volume and renal function were made.

The individual variations in response are noted, namely (1) the development of an intense proteinuria in a patient convalescent from rheumatic 
fever, without evidence of impaired renal function; (2) the retention of water with peripheral edema, hydrothorax and pericardial effusion, and the poor utilization of the injected protein in a woman with probable generalized vascular disease; (3) the excellent utilization, but eventual development of signs of cardio-respiratory embarrassment in a young woman in fair health except for moderate undernutrition; and (4) the modification of the response in a normal young male by other dietary factors. The mechanisms of these reactions are discussed.

It is felt that proteinuria will develop eventually in any patient when saturation with albumin has occurred and that this is probably not due to renal damage, but represents a physiological response when the maximum reabsorptive capacity of the renal tubules for protein is exceeded.

\section{ACKNOWLEDGMENT}

The authors express their appreciation to Dr. Lawrence A. Kohn, Department of Medicine, University of Rochester, for the determinations of plasma and blood volumes, and to Dr. Eric L. Alling, Department of Pathology, University of Rochester, for analysis of the serum proteins by electrophoresis.

\section{BIBLIOGRAPHY}

1. Allison, James B., Anderson, John A., and Seeley, Robert D., The determination of the nitrogen balance index in normal and hypoproteinemic dogs. Ann. New York Acad. Sc., 1946, 47, 245.

2. Peters, John P., Nitrogen metabolism in acute and chronic disease. Ann. New York Acad. Sc., 1946, 47, 327.

3. Peters, John P., and Van Slyke, Donald D., Quantitative Clinical Chemistry. Interpretations, Vol. I. Williams and Wilkins Co., Baltimore, Md., 1946.

4. Bassett, S. H., Woods, R. R., Shull, F. W., and Madden, S. C., Parenterally administered amino acids as a source of protein in man. New England J. Med., 1944, 230, 106.

5. Elman, R., Parenteral Alimentation. P. B. Hoeber, New York, 1947.

6. Madden, S. C., Remington, J. H., Martin, F. J. C., Woods, R. R., and Shull, F. W., Amino acids in therapy of disease; parenteral and oral administrations compared. Surg., Gynec. \& Obst., 1946, 82, 131.

7. Meyer, F. L., Hirshfeld, J. W., Abbott, W. E., Pilling, M. A., Williams, H. H., and Richards, A. J., Nitrogen balance and blood volume studies in man during and following repeated plasma transfusions. Am. J. M. Sc., 1947, 213, 160.
8. Elman, R., and Davey, H. W., Studies on hypoalbuminemia produced by protein-deficient diets. III. The correction of hypoalbuminemia in dogs by means of large plasma transfusions. J. Exper. Med., 1943, 77, 1.

9. Holman, Russell L., Mahoney, Earle B., and Whipple, George $\mathrm{H}$., Blood plasma protein given by vein utilized in body metabolism; a dynamic equilibrium between plasma and tissue proteins. $\mathrm{J}$. Exper. Med., 1934, 59, 269.

10. Brand, E., Kassell, B., and Saidel, L. T., Chemical, clinical, and immunological studies of the products of human plasma fractionation. III. Amino acid composition of plasma proteins. J. Clin. Invest., 1944, 23, 437.

11. Hegsted, D. M., Hay, A. L., and Stare, F. J., Chemical, clinical, and immunological studies on the products of human plasma fractionation. XXIV. Studies on the nutritive value of human plasma fractions. J. Clin. Invest., 1945, 24, 657.

12. Eckhardt, Richard D., Lewis, Jessica H., Murphy, T. Lynch, Batchelor, William H., and Davidson, Charles S., Chemical, clinical and immunological studies on the products of human plasma fractionation. XXXIV. Comparative studies on the nutritive value of orally and intravenously administered human serum albumin in man. J. Clin. Invest., 1948, 27, 119.

13. Albright, F., Forbes, A. P., and Reifenstein, E. C., Jr., The fate of plasma protein administered intravenously. Tr. A. Am. Physicians, 1946, 59, 221.

14. Bassett, S. H., and Van Alstine, H. E., Mineral changes of man. IV. Variations in the mineral content of diets having a constant raw weight formula. J. Nutrition, 1935, 9, 175.

15. Washburn, M. L., and Shear, M. J., Composition of bone. XIII. Direct gravimetric determination of calcium, magnesium and phosphorus. J. Biol. Chem., 1932, 99, 21.

16. Fiske, C. H., and Subbarow, Y., Colorimetric determination of phosphorus. J. Biol. Chem., 1925, 66, 375.

17. Berry, J. W., Chappell, D. W., and Barnes, R. B., Improved method of flame photometry. Indust. \& Engin. Chem., 1946, 18, 19.

18. Peters, J. P., and Van Slyke, D. D., Quantitative Clinical Chemistry. Methods, Vol. II. Williams \& Wilkins Co., Baltimore, Md., 1932.

19. Kingsley, G. R., Direct biuret method for the determination of serum proteins as applied to photoelectric and visual colorimetry. J. Lab. \& Clin. Med., 1942, 27, 840.

20. Zeldis, L. J., and Alling, E. L., Plasma protein metabolism-electrophoretic studies. J. Exper. Med., 1945, 81, 515.

21. Gilbon, J. G., 2nd, and Evans, Wm., Jr., Clinical application of a method employing the blue azo dye "Evans Blue" and the spectrophotometer. J. Clin. Invest., 1937, 16, 301. 
22. Wintrobe, Maxwell M., Clinical Hematology. Lea \& Febiger, Philadelphia, 1946.

23. Reifenstein, E. C., Jr., Albright, F., and Wells, S., The accumulation, interpretation and presentation of data pertaining to metabolic balances, notably those of calcium, phosphorus and nitrogen. J. Clin. Endocrinol., 1945, 5, 367.

24. Albright, F., Bauer, W., Ropes, M., and Aub, J. C., Studies of calcium and phosphorus metabolism. IV. The effect of parathyroid hormone. J. Clin. Invest., 1929, 7, 139.

25. Albright, F., Parson, W., and Bloomberg, E., Cushing's syndrome interpreted as hyperadrenocorticism leading to hypergluconeogenesia; results of treatment with testosterone propionate. J. Clin. Endocrinol., 1941, 1, 375.

26. Riegel, C., Fletcher, A. G., Jr., and Gimbel, N. S., A study with human serum albumin as the source of protein for early postoperative patients. Report to American Red Cross on the National Blood Program, April, 1948.
27. Drinker, C. K., The formation and movement of lymph. (The George Brown Memorial Lecture.) Am. Heart J., 1939, 18, 389.

28. Terry, R., Sandrock, W. E., Nye, R. E., Jr., and Whipple, G. H., Parenteral plasma protein maintains nitrogen equilibrium over long periods. J. Exper. Med., 1948, 87, 547.

29. Gimbel, N. S., and Riegel, C., A study in the nitrogen balance of human serum albumin administered intravenously and orally. Report to American Red Cross on the National Blood Program, April, 1948.

30. Monke, J. V., and Yuile, C. L., The renal clearance of hemoglobin in the dog. J. Exper. Med., 1940, 72, 149.

31. Terry, R., Hawkins, W., Church, E. H., and Whipple, G. H., Proteinuria related to hyperproteinemia in dogs following plasma given parenterally (a renal threshold for plasma proteins). J. Exper. Med., 1948, 87, 561.

32. Rather, Lelland J., On the problem of renal tubular reabsorption of protein. Stanford Med. Bull., 1948, 6, 117. 